\title{
p53 codon 72 polymorphism, loss of heterozygosity and high-risk human papillomavirus infection in a low-incidence German esophageal squamous cell carcinoma patient cohort
}

\author{
ANNETTE PANTELIS $^{1 *}$, DIMITRIOS PANTELIS ${ }^{2 *}$, PETRA RUEMMELE ${ }^{4}$, ARNDT HARTMANN $^{4}$, \\ FERDINAND HOFSTAEDTER ${ }^{4}$, REINHARD BUETTNER ${ }^{3}$, FRIEDRICH BOOTZ ${ }^{1}$ and ROBERT STOEHR ${ }^{5}$ \\ Departments of ${ }^{1}$ Otorhinolaryngology/Plastic Surgery and ${ }^{2}$ Surgery, and ${ }^{3}$ Institute of Pathology, University of Bonn, \\ 53105 Bonn; ${ }^{4}$ Institute of Pathology, ${ }^{5}$ Department of Urology, University of Regensburg, 93042 Regensburg, Germany
}

Received December 21, 2006; Accepted January 25, 2007

\begin{abstract}
Epidemiological studies in endemic geographic regions for esophageal squamous cell carcinoma (ESCC) suggested a number of risk factors, including modifications of the $\mathrm{p} 53$ tumor suppressor by codon Arg72Pro polymorphism, loss of heterozygosity ( $\mathrm{LOH})$ or human papillomavirus type 16 or 18 (HPV 16/18) infection. The p53 Arg72 variant has been suggested to be a high-risk factor in HPV-associated tumors. The present study analysed these associations in a low incidence geographic region in Germany. Fifty-three paraffinembedded tumors and 53 surrounding normal squamous epithelium were investigated. For detection of p53 codon Arg72Pro polymorphism, direct sequencing for exon 4 was conducted. $\mathrm{LOH}$ analysis was performed using three microsatellite markers at the p53 gene locus, and all cases were screened for high-risk HPV infection (HPV 16 and 18) with primer specific PCR and confirmed by sequencing. The p53 codon 72 genotype distribution was identical to published studies of normal Caucasian population, suggesting no general influence of this polymorphism on esophageal cancer risk in Germany. One case showed a p53 mutation in exon 4. p53 $\mathrm{LOH}$ was found in 13/44 (30\%) informative cases without any correlation to histopathological characteristics. Of 53 (17\%) samples, 9 showed HPV 16 or 18 infection. We found no association between p53 codon 72 genotypes and increasing HPV infection rates. Interestingly, 8/9 HPV-positive cases showed at least one p53 Arg72 allele. These results indicate an important role of p53 in ESCC also in low-incidence
\end{abstract}

Correspondence to: Dr Annette Pantelis, Department of Otorhinolaryngology/Plastic Surgery, Rheinische FriedrichWilhelms-University Bonn, Sigmund-Freud-Str. 25, 53105 Bonn, Germany

E-mail: annette.pantelis@ukb.uni-bonn.de

${ }^{*}$ Contributed equally

Key words: esophageal squamous cell carcinoma, p53 codon 72 polymorphism, loss of heterozygosity, human papillomavirus infection regions. In combination with the p53 Arg72 variant HPV infection could contribute to the risk of ESCC development in these cases, as has been demonstrated for high-risk regions.

\section{Introduction}

Esophageal squamous cell carcinoma (ESCC) is one of the six most common malignant diseases in the world with a remarkable geographical distribution (1). Environmental exposures such as tobacco, alcohol, chronic mucosal irritation and ethnic background increase the risk of developing ESCC (2). Moreover, genetic changes affecting the p53 tumor suppressor such as different mutations, loss of heterozygosity (LOH) and high-risk human papillomavirus (HPV) infection are important for carcinogenesis in the esophagus. The p53 gene has a common sequence polymorphism resulting in either proline (CCC) or arginine (CGC) at amino-acid position 72 . This polymorphism occurs in the proline-rich domain of the protein, which is necessary to induce apoptosis. The Arg72 variant induces apoptosis more effectively than does the Pro72 variant (3). In smokers, several studies have suggested an increased risk of lung cancer associated with the Pro/Pro genotype $(4,5)$. In contrast, Arg/Arg homozygotes are frequently found in non-smoking patients with lung cancer $(5,6)$.

Allelic deletions detected as LOH have been proved useful for mapping regions of DNA that contain tumor suppressor genes (7). Cancer lesions show a high frequency of LOH in the p53 tumor suppressor gene locus on chromosome 17p13.1 measured by repetitive DNA sequences (microsatellites), scattered widely within the genome (8). The p53 codon 72 polymorphism is also affected by $\mathrm{LOH}$ in tumors (9). Either arginine or proline could be lost by this mechanism. With the progression of (pre-) cancerous lesions in the esophagus, the rate of $\mathrm{LOH}$ at $17 \mathrm{p} 13.1$ raising the possibility that these changes may be one of the important mechanisms driving precancerous lesions to esophageal squamous cell carcinoma (1).

It was found previously that the p53 codon 72 arginine genotype is a high-risk factor for development of HPV associated cervical carcinoma (10). The arginine allele was found to be more susceptible to degradation by HPV E6 protein than the proline allele, resulting in a high frequency 
Table I. Tumor staging and grading of the ESCC cohort.

\begin{tabular}{lcccccccccc}
\hline TNM & $\mathrm{T}_{\text {Cis }}$ & $\mathrm{T}_{1}$ & $\mathrm{~T}_{2}$ & $\mathrm{~T}_{3}$ & $\mathrm{~T}_{4}$ & $\mathrm{G} 1$ & $\mathrm{G} 2$ & $\mathrm{G} 3$ & $\mathrm{~N}_{0}$ & $\mathrm{~N}_{1}$ \\
\hline Cases & 1 & 6 & 5 & 39 & 2 & 2 & 27 & 23 & 24 & 29 \\
Percentage & $(2 \%)$ & $(11 \%)$ & $(9 \%)$ & $(74 \%)$ & $(4 \%)$ & $(4 \%)$ & $(52 \%)$ & $(44 \%)$ & $(45 \%)$ & $(55 \%)$ \\
\hline
\end{tabular}

Table II. Primer sequence and PCR conditions.

PCR conditions

\begin{tabular}{|c|c|c|}
\hline \multicolumn{3}{|l|}{ Microsatellite markers } \\
\hline D2S123 (2p21-16.3) & $\begin{array}{l}\text { Sense: AAACAGGATGCCTGCCTTTA } \\
\text { Antisense: GGACTTTCCACCTATGGGAC }\end{array}$ & $\begin{array}{l}2 \mathrm{~min} \text { at } 95^{\circ} \mathrm{C} ; 1 \mathrm{~min} \text { at } 95^{\circ} \mathrm{C}, 1 \mathrm{~min} \text { at } 60^{\circ} \mathrm{C}, 1 \mathrm{~min} \text { at } \\
72^{\circ} \mathrm{C}(35 \text { cycles }) ; 8 \min \text { at } 72^{\circ} \mathrm{C} \text {; cooled to } 8^{\circ} \mathrm{C}\end{array}$ \\
\hline ß-globin & $\begin{array}{l}\text { Sense: GTTGGCCAATCTACTCCCAGG } \\
\text { Antisense: CTCACTCAGTGTGGCAAAG }\end{array}$ & $\begin{array}{l}2 \mathrm{~min} \text { at } 95^{\circ} \mathrm{C} ; 1 \mathrm{~min} \text { at } 95^{\circ} \mathrm{C}, 1 \mathrm{~min} \text { at } 60^{\circ} \mathrm{C}, 1 \mathrm{~min} \text { at } \\
72^{\circ} \mathrm{C}(50 \text { cycles }) ; 8 \text { min at } 72^{\circ} \mathrm{C} \text {; cooled to } 8^{\circ} \mathrm{C}\end{array}$ \\
\hline \multicolumn{3}{|l|}{ P53 sequence analysis } \\
\hline Exon 4 & $\begin{array}{l}\text { Sense: TTGCCGTCCCAAGCAAGT } \\
\text { Antisense: GGGAAGGGACAGAAGATG }\end{array}$ & $\begin{array}{l}3 \mathrm{~min} \text { at } 95^{\circ} \mathrm{C} ; 1 \mathrm{~min} \text { at } 95^{\circ} \mathrm{C}, 1 \mathrm{~min} \text { at } 56^{\circ} \mathrm{C}, 1 \mathrm{~min} \text { at } \\
72^{\circ} \mathrm{C}(35 \text { cycles }) ; 8 \text { min at } 72^{\circ} \mathrm{C} \text {; cooled to } 8^{\circ} \mathrm{C}\end{array}$ \\
\hline \multicolumn{3}{|l|}{ LOH-p53 analysis } \\
\hline Tp53alu (17p13.1) & $\begin{array}{l}\text { Sense: CGAGGAGGTTGCAGTAAGCGGA } \\
\text { Antisense: ACAGCTCCTTTAATGGCAG }\end{array}$ & $\begin{array}{l}3 \mathrm{~min} \text { at } 95^{\circ} \mathrm{C} ; 1 \mathrm{~min} \text { at } 95^{\circ} \mathrm{C}, 1 \mathrm{~min} \text { at } 55^{\circ} \mathrm{C}, 1 \mathrm{~min} \text { at } \\
72^{\circ} \mathrm{C}(40 \text { cycles }) ; 10 \mathrm{~min} \text { at } 72^{\circ} \mathrm{C} \text {; cooled to } 8^{\circ} \mathrm{C}\end{array}$ \\
\hline D17S918 (17p12) & $\begin{array}{l}\text { Sense: TGTTGAGCTTTCCTGTAATC } \\
\text { Antisense: TTCCTCACACAACCTATTGA }\end{array}$ & $\begin{array}{l}3 \mathrm{~min} \text { at } 95^{\circ} \mathrm{C} ; 1 \mathrm{~min} \text { at } 95^{\circ} \mathrm{C}, 1 \mathrm{~min} \text { at } 51^{\circ} \mathrm{C}, 1 \mathrm{~min} \text { at } \\
72^{\circ} \mathrm{C}(45 \text { cycles }) ; 8 \text { min at } 72^{\circ} \mathrm{C} \text {; cooled to } 8^{\circ} \mathrm{C}\end{array}$ \\
\hline D17S786 (17p13.1) & $\begin{array}{l}\text { Sense: TAGAGGGATAGGTAGCCGAG } \\
\text { Antisense: GGATTTGGGCTCTTTTGTAA }\end{array}$ & $\begin{array}{l}2 \mathrm{~min} \text { at } 95^{\circ} \mathrm{C} ; 1 \mathrm{~min} \text { at } 95^{\circ} \mathrm{C}, 1 \mathrm{~min} \text { at } 51^{\circ} \mathrm{C}, 1 \mathrm{~min} \text { at } \\
72^{\circ} \mathrm{C}(35 \text { cycles }) ; 8 \text { min at } 72^{\circ} \mathrm{C} \text {; cooled to } 8^{\circ} \mathrm{C}\end{array}$ \\
\hline \multicolumn{3}{|l|}{ Detection of HPV-DNA } \\
\hline HPV 16 & $\begin{array}{l}\text { Sense: GCAACCAGAGACAACTGATC } \\
\text { Antisense: TTGTAATGGGCTCTGTCCG }\end{array}$ & $\begin{array}{l}10 \mathrm{~min} \text { at } 94^{\circ} \mathrm{C} ; 1 \mathrm{~min} \text { at } 94^{\circ} \mathrm{C}, 2 \mathrm{~min} \text { at } 55^{\circ} \mathrm{C}, 2 \mathrm{~min} \text { at } \\
72^{\circ} \mathrm{C}(40 \text { cycles }) ; 8 \text { min at } 72^{\circ} \mathrm{C} \text {; cooled to } 8^{\circ} \mathrm{C}\end{array}$ \\
\hline HPV 18 & $\begin{array}{l}\text { Sense: TCACGAGCAATTAAGCGACT } \\
\text { Antisense: CTGAGCTTTCTACTACTAGC }\end{array}$ & $\begin{array}{l}10 \mathrm{~min} \text { at } 94^{\circ} \mathrm{C} ; 1 \mathrm{~min} \text { at } 94^{\circ} \mathrm{C}, 2 \mathrm{~min} \text { at } 55^{\circ} \mathrm{C}, 2 \mathrm{~min} \text { at } \\
72^{\circ} \mathrm{C}(40 \text { cycles }) ; 8 \text { min at } 72^{\circ} \mathrm{C} \text {; cooled to } 8^{\circ} \mathrm{C}\end{array}$ \\
\hline
\end{tabular}

of cervical SCC in individuals homozygous for arginine at the codon (9). This raises the possibility that homozygosity for codon Arg72 may lead to an increased susceptibility to other types of HPV related cancers as well. HPV infection occurs infrequently in association with ESCC in patients from North America $(11,12)$ but regularly in high-incidence areas like P.R. China. The p53 codon Arg72 homozygous genotype is one of the high-risk genetic factors for HPV associated ESCC among the Chinese population (13). Especially HPV 16 and 18 encode two major oncoproteins, E6 and E7, and are implicated in the pathogenesis of squamous cell carcinoma (SCC) by deactivating the p53 tumor suppressor (14).

In the present study, we examined the relationship between the distribution of the p53 codon Arg72Pro genotype, loss of heterozygosity at the p53 gene locus, and the presence of HPV 16 and 18 DNA in a series of ESCCs and normal surrounding tissues in an ESCC patient cohort from Germany, a low incidence geographic region.

\section{Materials and methods}

Cancer and normal tissue probes. Fifty-three formalin-fixed, paraffin-embedded ESCCs (51 males and two females) with a median age of 58 years (range, 39-76 years) and 53 corresponding samples of histopathological normal squamous epithelium were included in this study. All cases were obtained from the archives of the Institute of Pathology, University of Regensburg and the Institute of Pathology, University of Bonn, Germany. The lesions were classified according to the International Union Against Cancer (UICC) guidelines (15). All patients gave informed consent for the study. The histopathological characteristics of the tumors are shown in Table I.

DNA isolation and quality control. DNA was extracted after manual microdissection of tumor and normal squamous epithelial cells. In brief, after deparaffinization and methylene 

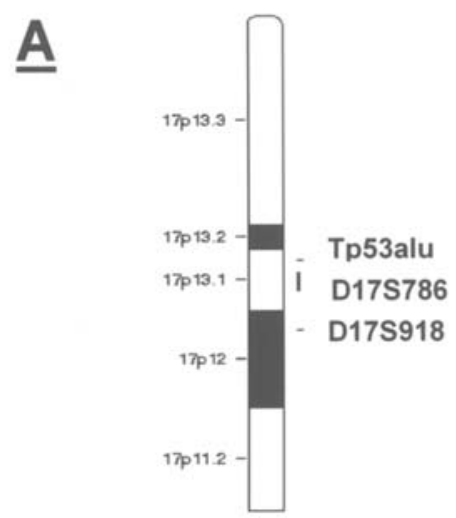

$\underline{B}$

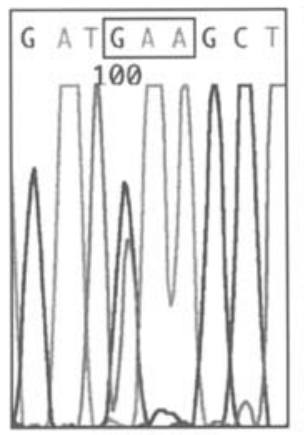

sense

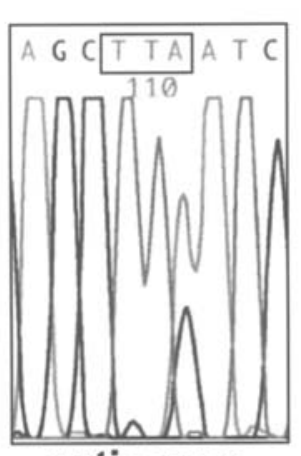

antisense

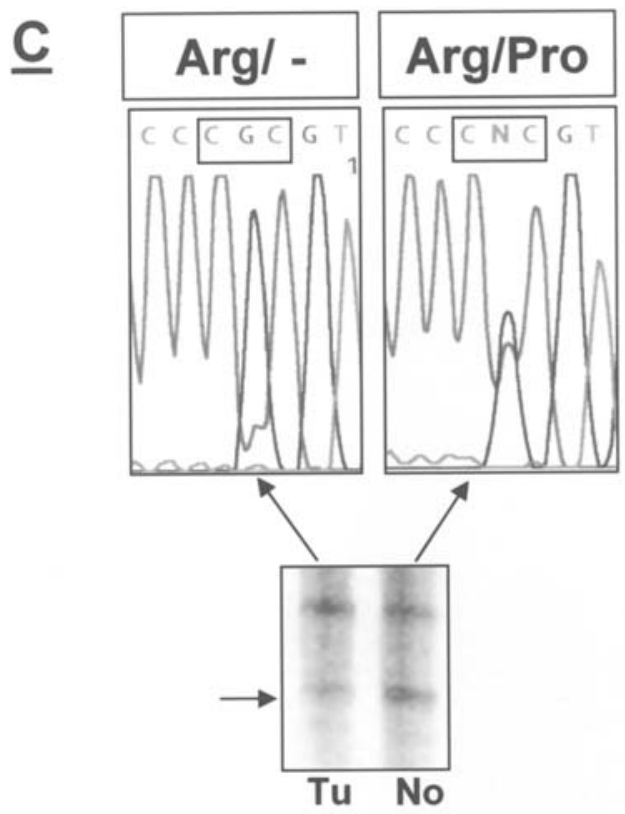

$\underline{\mathbf{D}}$

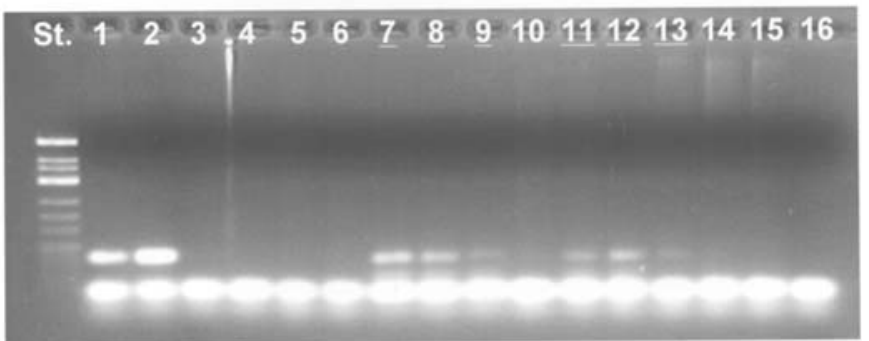

Figure 1. (A) Location of the microsatellite markers for p53 LOH analysis. (B) p53 exon 4 mutation, codon 62 (GAA to TAA) detected in one ESCC (sex, male; age, 76 years; diagnosis, pT3G2N1MX; no HPV 16/18 infection, LOH in the marker Tp53alu). Sense and antisense direction is shown. (C) p53 codon 72 sequencing and $\mathrm{LOH}$ of the proline allele in the tumor compared with the normal tissue. Note loss of the proline allele in the tumor. (D) Detection of HPV 16 DNA in ESCC. Lane 1 and 2, positive controls; lanes 3-15, ESCC samples; lane 16, negative control. ESCC with positive HPV 16 signals are marked (underlined numbers).

blue staining, microdissection was performed under an inverted microscope. A purity of at least $80 \%$ of tumor cells was obtained. DNA was extracted using the High Pure PCR template preparation kit (Roche Diagnostics GmbH, Mannheim, Germany) according to the manufacturer's instructions. DNA quality was assured by performing a PCR amplification of the polymorphic microsatellite marker D2S123 and a 540-bp B-globin fragment (for primer sequences and PCR conditions see Table II). PCR products were separated using $2 \%$ agarose gels and visualized under ultraviolet light by using $0.05 \%$ ethidium bromide. Only DNA samples showing at least one specific PCR product were used for further analysis.

Genomic DNA sequencing of p53. Exon 4 of the p53 gene containing the polymorphic sequence variant at codon 72 was analysed using direct genomic sequencing. Primer sequences and PCR conditions are shown in Table II. PCR products containing exon 4 were purified by polyethylene glycol precipitation (equal volume of PCR product and PEG-Mix containing 26\% PEG8000, $0.6 \mathrm{~mol} / \mathrm{l} \mathrm{Na}$ acetate, $\mathrm{pH} 5.5$, $6.6 \mathrm{mmol} / 1 \mathrm{MgCl}_{2}$ ). Purified DNA was sequenced in both directions using the PRISM Ready Dye Terminator cycle sequencing kit (Applied Biosystems GmbH, Weiterstadt, Germany) and an Applied Biosystems 373 sequencer. Sequencing reaction was as follows: initial incubation for $2 \mathrm{~min}$ at $96^{\circ} \mathrm{C}, 25$ cycles of denaturation for $15 \mathrm{sec}$ at $96^{\circ} \mathrm{C}, 15-\mathrm{sec}$ annealing at $56^{\circ} \mathrm{C}$ and 4-min elongation at $60^{\circ} \mathrm{C}$.

p53 deletion analysis. $\mathrm{LOH}$ analysis for the p53 gene locus on chromosome $17 \mathrm{p} 13.1$ was performed using three polymorphic microsatellite markers (Tp53alu, D17S918, D17S786, see Table II and Fig. 1A). Location of the markers and primer sequences were taken from the Genome Database (www.gdb. org). All primers were obtained from Proligo France SAS (Paris, France). Matched normal/tumor DNA samples were amplified by PCR in a $25-\mu 1$ volume containing $0.2 \mathrm{mmol} / 1$ dNTP, $0.3 \mu \mathrm{mol} / 1$ primers, $1.5 \mathrm{mmol} / 1 \mathrm{MgCl}_{2}, 0.5 \mathrm{U}$ Taq polymerase (Roche Diagnostics $\mathrm{GmbH}$, Mannheim, Germany), 


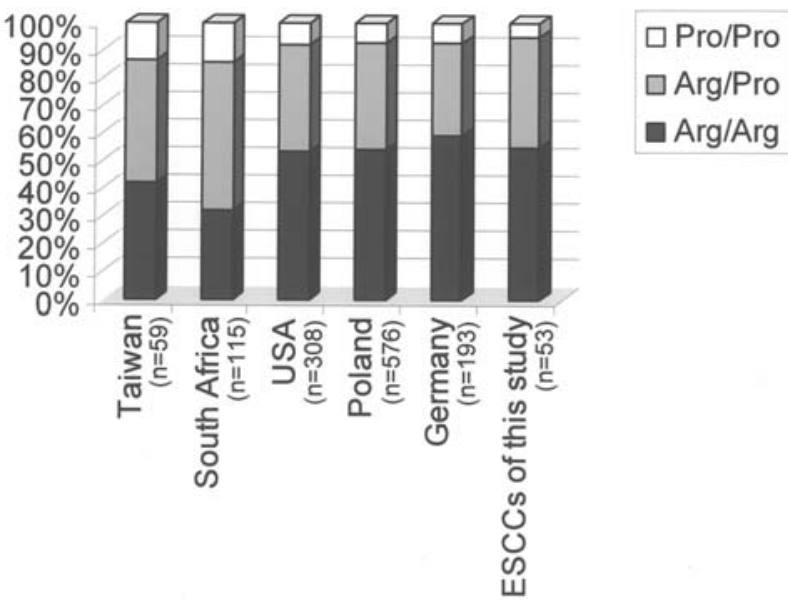

Figure 2. Comparison between the p53 codon 72 polymorphism distribution in normal control groups from various case/control studies (30-34) and ESCC cases from this study. Analysed ESCC cases showed a very similar distribution to the control groups of other studies on Caucasians (USA, Poland, Germany). Studies from South Africa and Taiwan clearly showed a different allele distribution with higher frequency of the proline allele in comparison to Caucasians. These regions are endemic for ESCC and are geographical high-risk populations for HPV-associated tumors. n, number of analysed cases.

using $100 \mathrm{ng}$ isolated DNA as a template. PCR conditions (Table II) were optimized by gradient PCR and were carried out in an MJ research thermocycler (PTC 100). The amplification products were detected by polyacrylamide gel electrophoresis and silver staining as described previously (16). The silverstained gels were assessed visually by two independent observers (AP and RS), and informative cases were scored as allelic loss when intensity of the signal for the tumor allele was decreased to at least $50 \%$ relative to the matched normal allele. To avoid errors due to preferential amplification of one allele during the PCR reaction, all detected allelic losses were verified by a second independent PCR reaction.

Detection of HPV 16/18 DNA. HPV type 16 and 18 specific PCR was performed as previously described (17). Matched normal and tumor tissues were screened for virus DNA using the primers and PCR conditions shown in Table II. Amplification was carried out in a $50-\mu 1$ reaction volume containing $0.1 \%$ Triton-X-100, $0.2 \mathrm{mmol} / 1 \mathrm{dNTPs}, 2 \mu \mathrm{mol} / \mathrm{l}$ primers, $1.5 \mathrm{mmol} / 1 \mathrm{MgCl}_{2}, 0.5 \mathrm{U}$ Taq polymerase and $100 \mathrm{ng}$ DNA as template. As positive controls HPV-16 positive CaSki- and HPV-18 positive HeLa cell lines were used. The amplification products were detected by agarose gel electrophoresis (3\%) and ethidium bromide staining. PCR products, indicating HPV infection of a patient, were sequenced as described above using sense PCR primers to verify the result. The received nucleotide sequence was used for standard nucleotide-nucleotide BLAST search (http://www.ncbi.nlm. nih.gov/BLAST) to show concordance of the sequence with the database entry for HPV 16/18.

\section{Results}

p53 codon 72 genotype distribution. The p53 codon 72 polymorphism $(\mathrm{C} / \mathrm{G})$ was examined by DNA sequencing for exon 4. The allelic distribution in the germline DNA of the patients was as follows: Arg/Arg, 29/53 (54.7\%); Arg/Pro, 21/53 (39.6\%); Pro/Pro, $3 / 53$ (5.7\%). In the corresponding ESCCs the following distribution was found: Arg/Arg, 31/53 (58.5\%); Arg/Pro, 16/53 (30.2\%); Pro/Pro, 6/53 (11.3\%). The differences in the allelic distribution could be explained by the results of the $\mathrm{LOH}$ analysis (see below). Lacking a healthy control group the distribution of the p53 codon 72 polymorphism in the germline DNA of our patient cohort was compared to data of healthy controls in previously published studies (30-34) (Fig. 2). Our patient cohort showed a very similar allelic distribution to the control groups of three studies investigating Caucasian populations. Studies from endemic regions for ESCC (Taiwan, South Africa) showed a clearly different distribution of the polymorphism. This indicates that the 553 codon 72 polymorphism is not correlated with an increased risk for ESCC in our cohort. There was also no correlation between any allelic variant and histopathological characteristics of the tumors. The sequence analysis of exon 4 revealed a nonsense mutation ( $\mathrm{G}$ to $\mathrm{T}$; GAA to TAA; Glu to STOP; codon 62) in 1/53 tumors (Fig. 1B). This patient also showed $\mathrm{LOH}$ of the remaining allele.

LOH analysis of the p53 locus. $\mathrm{LOH}$ analysis for the $\mathrm{p} 53$ gene locus on chromosome 17p13.1 was performed using three polymorphic microsatellite markers. Of 53 patients, 44 showed heterozygosity in at least one microsatellite marker analysed, eight patients were homozygous for all three markers, and DNA from one tumor showed no amplification products at all. Overall, 13/44 (30\%) of the informative cases showed $\mathrm{LOH}$ in the analysed p53 areas without any correlation to histopathological characteristics. LOH appears in early tumor stages such as T1 but also in T4 tumors. Of 13 patients with $\mathrm{LOH}, 5$ were heterozygous for the codon 72 polymorphism and a loss of the Arg or Pro allele was analysed. Of 5 (40\%) tumors, 2 showed loss of the Pro allele, and $3(60 \%)$ showed loss of the Arg allele (Fig. 1C). Therefore the allelic distribution varied between the germline DNA of the patients and the corresponding ESCCs.

HPV 16 and 18 detection. Matched normal and tumor tissues were screened for HPV 16 and 18 DNA with virus-specific primers. Of $53(17 \%)$ of the samples, 9 showed HPV 16 or 18 infection (Fig. 1D). All cases were confirmed by sequencing. We found the HPV DNA both in the tumor and in the surrounding squamous epithelium. Six samples contained the HPV 16 virus, and three contained the HPV 18 virus type. We did not find an infection with both virus types. Of 6 (17\%) of the HPV 16-positive samples, 1 was homozygous for the arginine allele, and $5(83 \%)$ were heterozygous. Of 3 (67\%) of the HPV 18-positive specimens, 2 showed the Arg/ Arg, and 1 (33\%) showed the Pro/Pro genotype. Therefore 8/9 (89\%) HPV-infected probes are associated with the arginine allele. In 3/8 (38\%) HPV-positive Arg-associated specimens $\mathrm{LOH}$ at the p53 gene locus was found.

\section{Discussion}

p53 gene alterations are initiating or very early events in SCC regardless of anatomic site and already evident in premalignant 
lesions (18). These alterations include p53 mutations and chromosomal deletions at the p53 gene locus. In addition, allelic variations in the coding region of p53 were also identified recently (3). The p53 codon Arg72 homozygous genotype is one of the high-risk genetic factors for HPVassociated ESCC among the Chinese population (13). In our study p53 codon 72 genotype distribution in ESCC patients was identical to healthy Caucasian control groups. This indicates that the p53 codon 72 polymorphism does not influence the general risk for ESCC in Germany. To our knowledge, this is the first study analysing the p53 Arg72Pro polymorphism in ESCC patients in a low endemic region.

Sequence analysis of exon 4 of the p53 gene revealed 1 case $(2 \%)$ with a nonsense mutation. This low frequency of mutations in exon 4 is in accordance with previous studies showing that p53 mutations are most frequently found in exons 5-9 in $\operatorname{ESCC}(20,21)$.

Deletion of $17 \mathrm{p}$ is very common in most tumor types and is the most frequent way to inactivate the remaining wildtype allele in a tumor with p53 mutation. We found that $30 \%$ of the tumors in our patient cohort showed LOH at chromosome region $17 \mathrm{p} 13.1$. There are several studies dealing with $\mathrm{p} 53$ deletion in ESCC. The detected rates of $\mathrm{LOH}$ vary from $55 \%$ to $80 \%$ (22-24). All of these studies analysed tumors from highrisk populations. This might explain the discrepancy to our findings of a lower rate of p53 LOH. Another reason could be that 9 of 44 tumors with interpretable results were informative for the microsatellite markers D17S918 and D17S786 but not for the Tp53alu marker. These markers are located downstream of the p53 gene locus, and therefore smaller deletions might have been missed in our study. Nevertheless our data indicate an important and early role of p53 alterations in esophageal carcinogenesis in a low-risk population. $\mathrm{LOH}$ also affected the polymorphic codon 72 region in exon 4 . Sixty percent of the ESCCs with $\mathrm{LOH}$ and both allelic variants in the corresponding germline DNA showed a deletion of the arginine allele and retention of the Pro72 variant. The Arg72 variant induces apoptosis more effectively than does the Pro72 variant (3). Therefore it might be speculated that preferred deletion of the Arg72 allele could generate cells which are more resistant to apoptotic stimuli. Experimental data for this hypothesis are missing. Large studies in different populations should be performed to clarify the importance of a possible preferential deletion of Arg72 in the esophageal carcinogenesis.

HPV may be a causative factor in carcinoma of the esophagus (17). The HPV infection rates range from $21 \%$ to $75 \%(13,19)$. E6 from HPV 16 and 18 is more effective in degradation of p53 Arg72 than p53 Pro72 in vitro. p53 Arg72 may therefore represent a risk factor for HPV-associated tumorigenesis (10). In the present study we detected a relatively low rate of HPV high-risk type 16 or 18 infection in the ESCCs from Germany. Only 9/53 (17\%) cases showed an infection with HPV 16 or 18 . Our results are in contrast to a previously published study by Awerkiew and co-workers (25), who found no HPV-positive ESCC in 23 patients from Germany but a high incidence (35\%) of Epstein-Barr-virus (EBV) in ESCC. Recently these authors showed that the presence of EBV in esophageal cancer is restricted to tumor infiltrating lymphocytes (26). Only one other study also detected EBV in ESCC but with a much lower frequency (8\%) (27). In addition, two studies from Greece and Thailand investigated EBV infection in ESCC and did not detect any positive tumors $(28,29)$ suggesting a minor role of EBV in ESCC.

Nevertheless, the important role of the p53 codon 72 polymorphism in HPV-associated cancer had already been demonstrated for ESCC in endemic regions (9). Interestingly, in our tumor cohort 8/9 (89\%) HPV-positive ESCC cases showed at least one p53 Arg72 allele. Because of the small overall number of HPV-positive tumors this difference did not reach statistical significance (data not shown). Of 8 (37.5\%) cases, 3 were homozygous for the Arg72 variant. In these cases fast degradation of the $\mathrm{p} 53$ protein by the E6 oncoprotein could have driven genomic instability and tumor initiation. Of $8(62.5 \%)$ cases, 5 displayed both allelic variants of the p53 gene. A supposed degradation of the Arg72 variant by E6 in these cases could lead to functional activity of only the Pro72 variant and to a decreased apoptotic sensitivity of the cells. This condition might also increase the risk for malignant transformation of the cells, but additional experimental data are needed to validate this hypothesis.

In summary, we showed that alterations of $\mathrm{p} 53$ play a considerable role in ESCC from a low-incidence German patient cohort. The distribution of the p53 codon 72 polymorphism seems not to be a general risk factor for ESCC in Caucasians. Even in a low-risk population, infection with HPV 16 and 18 is detectable in ESCC patients and might increase the risk for ESCC. In these cases, the p53 Arg72 allele could contribute to a higher risk for ESCC development by quick degradation of p53 via the viral E6 oncoprotein, as is known to occur in patients from high-incidence geographical regions.

\section{Acknowledgements}

The authors are grateful to Kornelia Elser for expert technical assistance.

\section{References}

1. An JY, Fan ZM, Gao SS, Zhuang ZH, Qin YR, Li JL, He X and Wang LD: Loss of heterozygosity in multistage carcinogenesis of esophageal carcinoma at high-incidence area in Henan Province, China. World J Gastroenterol 11: 2055-2060, 2005.

2. Crew KD and Neugut AI: Epidemiology of upper gastrointestinal malignancies. Semin Oncol 31: 450-464, 2004.

3. Dumont P, Leu JI, Della Pietra AC III, George DL and Murphy M: The codon 72 polymorphic variants of p53 have markedly different apoptotic potential. Nat Genet 33: 357-365, 2003

4. Kawajiri K, Nakachi K, Imai K, Watanabe J and Hayashi S: Germ line polymorphisms of p53 and CYP1A1 genes involved in human lung cancer. Carcinogenesis 14: 1085-1089, 1993.

5. Wang YC, Chen CY, Chen SK, Chang YY and Lin P: p53 codon 72 polymorphism in Taiwanese lung cancer patients: association with lung cancer susceptibility and prognosis. Clin Cancer Res 5: 129-134, 1999.

6. Murata M, Tagawa M, Kimura M, Kimura H, Watanabe S and Saisho H: Analysis of a germ line polymorphism of the p53 gene in lung cancer patients; discrete results with smoking history. Carcinogenesis 17: 261-264, 1996.

7. Thiagalingam S, Foy RL, Cheng KH, Lee HJ, Thiagalingam A and Ponte JF: Loss of heterozygosity as a predictor to map tumor suppressor genes in cancer: molecular basis of its occurrence. Curr Opin Oncol 14: 65-72, 2002.

8. Cullis CA: The use of DNA polymorphisms in genetic mapping. Genet Eng 24: 179-189, 2002.

9. Kawaguchi H, Ohno S, Araki K, Miyazaki M, Saeki H, Watanabe M, Tanaka S and Sugimachi K: p53 polymorphism in human papillomavirus-associated esophageal cancer. Cancer Res 60: 2753-2755, 2000 
10. Storey A, Thomas M, Kalita A, Harwood C, Gardiol D, Mantovani F, Breuer J, Leigh IM, Matlashewski G and Banks L: Role of a 553 polymorphism in the development of human papilloma-virus-associated cancer. Nature 393: 229-234, 1998.

11. Turner JR, Shen LH, Crum CP, Dean PJ and Odze RD: Low prevalence of human papillomavirus infection in esophageal squamous cell carcinomas from North America: analysis by a highly sensitive and specific polymerase chain reaction-based approach. Hum Pathol 28: 174-178, 1997.

12. Kamath AM, Wu TT, Heitmiller R, Daniel R and Shah KV: Investigation of the association of esophageal carcinoma with human papillomaviruses. Dis Esophagus 13: 122-124, 2000.

13. Li T, Lu ZM, Guo M, Wu QJ, Chen KN, Xing HP, Mei Q and Ke Y: p53 codon 72 polymorphism $(\mathrm{C} / \mathrm{G})$ and the risk of human papillomavirus-associated carcinomas in China. Cancer 95: 2571-2576, 2002.

14. Scheffner M, Werness BA, Huibregtse JM, Levine AJ and Howley PM: The E6 oncoprotein encoded by human papillomavirus types 16 and 18 promotes the degradation of p53. Cell 63: 1129-1136, 1990.

15. Sobin LH and Wittekind C: TNM Classification of Malignant Tumors. 6th edition. Wiley-Liss, New York, 2002.

16. Schlegel J, Bocker T, Zirngibl H, Hofstaedter F and Ruschoff J: Detection of microsatellite instability in human colorectal carcinomas using a non-radioactive PCR-based screening technique. Virchows Arch 426: 223-227, 1995.

17. Toh Y, Kuwano H, Tanaka S, Baba K, Matsuda H, Sugimachi K and Mori R: Detection of human papillomavirus DNA in esophageal carcinoma in Japan by polymerase chain reaction. Cancer 70: 2234-2238, 1992.

18. Mandard AM, Hainaut P and Hollstein M: Genetic steps in the development of squamous cell carcinoma of the esophagus. Mutat Res 462: 335-342, 2000.

19. He D, Zhang DK, Lam KY, Ma L, Ngan HY, Liu SS and Tsao SW: Prevalence of HPV infection in esophageal squamous cell carcinoma in Chinese patients and its relationship to the p53 gene mutation. Int J Cancer 72: 959-964, 1997.

20. Cao W, Chen X, Dai H, Wang H, Shen B, Chu D, McAfee T and Zhang ZF: Mutational spectra of p53 in geographically localized esophageal squamous cell carcinoma groups in China. Cancer 101: 834-844, 2004.

21. Putz A, Hartmann AA, Fontes PR, Alexandre CO, Silveira DA, Klug SJ and Rabes HM: TP53 mutation pattern of esophageal squamous cell carcinomas in a high risk area (Southern Brazil): role of life style factors. Int J Cancer 98: 99-105, 2002.

22. Aoki T, Mori T, Du X, Nishira T, Matsubara T and Nakamura Y: Allelotype study of esophageal carcinoma. Genes Chromosomes Cancer 10: 177-182, 1994.

23. Shibagaki I, Shimada Y, Wagata T, Ikenaga M, Imamura M and Ishizaki K: Allelotype analysis of esophageal squamous cell carcinoma. Cancer Res 54: 2996-3000, 1994.
24. Hu N, Huang J, Emmert-Buck MR, Tang ZZ, Roth MJ, Wang C, Dawsey SM, Li G, Li WJ, Wang QH, Han XY, Ding T, Giffen C, Goldstein AM and Taylor PR: Frequent inactivation of the TP53 gene in esophageal squamous cell carcinoma from a high-risk population in China. Clin Cancer Res 7: 883-891, 2001.

25. Awerkiew S, Bollschweiler E, Metzger R, Schneider PM, Hölscher AH and Pfister H: Esophageal cancer in Germany is associated with Epstein-Barr-virus but not with papillomaviruses. Med Microbiol Immunol 192: 137-140, 2003.

26. Awerkiew S, Hausen AZ, Baldus SE, Holscher AH, Sidorenko SI, Kutsev SI and Pfister HJ: Presence of Epstein-Barr virus in esophageal cancer is restricted to tumor infiltrating lymphocytes. Med Microbiol Immunol 194: 187-191, 2005.

27. Jenkins TD, Nakagawa $\mathrm{H}$ and Rustgi AK: The association of Epstein-Barr virus DNA with esophageal squamous cell carcinoma. Oncogene 13: 1809-1813, 1996.

28. Lyronis ID, Baritaki S, Bizakis I, Tsardi M and Spandidos DA: Evaluation of the prevalence of human papillomavirus and Epstein-Barr virus in esophageal squamous cell carcinomas. Int J Biol Markers 20: 5-10, 2005.

29. Sunpaweravong S, Mitarnum W and Puttawibul P: Absence of Epstein-Barr virus in esophageal squamous cell carcinoma. Dis Esophagus 18: 398-399, 2005

30. Chen WC, Tsai FJ, Wu JY, Wu HC, Lu HF and Li CW: Distributions of p53 codon 72 polymorphism in bladder cancer proline form is prominent in invasive tumor. Urol Res 28: 293-296, 2000.

31. Vos M, Adams CH, Victor TC and van Helden PD: Polymorphisms and mutations found in the regions flanking exon 5 to 8 of the TP53 gene in a population at high risk for esophageal cancer in South Africa. Cancer Genet Cytogenet 140: 23-30, 2003.

32. Shen H, Liu Z, Strom SS, Spitz MR, Lee JE, Gershenwald JE, Ross MI, Mansfield PE, Duvic M, Ananthaswamy $\mathrm{HN}$ and Wei Q: p53 codon 72 Arg homozygotes are associated with an increased risk of cutaneous melanoma. J Invest Dermatol 121: 1510-1514, 2003

33. Szymanowska A, Jassem E, Dziadziuszko R, Borg A, Limon J, Kobierska-Gulida G, Rzyman W and Jassem J: Increased risk of non-small lung cancer and frequency of somatic TP53 gene mutations in Pro72 carriers of TP53 Arg72Pro polymorphism. Lung Cancer 52: 9-14, 2006.

34. Scheckenbach K, Lieven O, Götte K, Bockmühl U, Zotz R, Bier $\mathrm{H}$ and Balz V: p53 codon 72 polymorphic variants, loss of allele-specific transcription, and human papilloma virus 16 and/or 18 E6 messenger RNA expression in squamous cell carcinoma of the head and neck. Cancer Epidemiol Biomarkers Rev 13: 1805-1809, 2004. 